УДК 342.733

DOI https://doi.org/10.32849/2663-5313/2020.11.27

\title{
Світлана Семіног,
}

канд. юрид. наук,

науковий співробітник

Науково-дослідного інституту приватного права і підприємництва

імені академіка Ф.Г. Бурчака Начіональної академї̈ правових наук України

\section{РЕАЛІЗАЦІЯ ПРАВА ДИТИНИ НА ОСВІТУ В УМОВАХ КАРАНТИННИХ ОБМЕЖЕНЬ}

Статтю присвячено аналізу теоретичних аспектів та практичних проблем щодо реалізачї̈ права дитини на освіту в умовах карантину під час пандемії COVID-19. Наголошено, шо імперативом реалізачії права дитини на освіту має бути одночасне забезпечення права на охорону здоров'я.

Проведено огляд міжнародно-правових договорів та проаналізовано ключові моменти внутрішнього законодавства у вказаному контексті. Визначено, що охорона здоров'я дитини та реалізація ї̈ права на освіту - ие основоположні завдання державної політики, яка, по-перше, обумовлює механізм забезпечення зазначених прав дитини міжнародними актами, по-друге, визначає систему норм права, спрямованих на захист прав дитини на начіональному рівні, по-третє, установлює юридично значущі дії, які реалізовуються відповідними інституціями та суб'єктами.

Розглянуто шляхх реалізації суб'єктивного права дитини на освіту під час дї карантинних обмежень. Окреслено й охарактеризовано форми здобуття освіти, за допомогою яких дитина має можливість отримувати безпечні умови під час навчального процесу: ие інституиійна, яка передбачає очну (денну) та дистаниійну форми навчання, та індивідуальна, яка забезпечує екстернатне, сімейне або домашне навчання.

У статті зосереджено увагу на дистаниійному навчанні. Підкреслено, що така форма здобуття освіти є нагальною в умовах свогодення та має сприяти забезпеченню гарантій шодо створення належних та безпечних умов зі здобуття освіти дітьми. Водночас визначено окремі недоліки та проблеми щодо дистаниійного навчання, наявні як із боку державного врегулювання в частині фінансування, забезпечення закладів освіти дистаниійними технологіями, організації освітнвого прочесу з використанням синхронного й асинхронного режимів навчання, так і щодо обмеження права дитини щодо повноцінного спілкування з однолітками, нервово-емоційного напруження та статистичного перенавантаження під час онлайн-занять.

Зроблено висновок, що право дитини на освіту закріплено нормативно-правовими актами, відповідно до яких органи державної влади забезпечують його реалізачію шляхом організаиії чітких дій відповідних інституцій та їхніх посадових осіб, а також дитина як специфічний суб'єкт права реалізовує своє суб'єктивне право на освіту за допомогою батьків та осіб, що їх замінюють, які вчиняють відповідні юридичні дії щодо створення безпечного освітнього процесу. Запропоновано вдосконалення нормативно-правої бази в контексті дистаниійного навчання шляхом ухвалення Державної програми щодо розвитку дистаниійної форми здобуття освіти.

Ключові слова: діти, права дитини, захист прав дитини, реалізація права дитини на освіту, денна форма навчання, дистанційна форма навчання, індивідуальна форма навчання, карантинні обмеження, пандемія, COVID-19.

Постановка проблеми. Незважаючи на епідемію коронавірусної інфекції COVID-19, у різних країнах світу 2020-2021 навчальний рік стартував восени. Так, наприклад, бельгійські, ірландські, польські, угорські школярі сіли за парти разом зі своїми українськими однолітками 1 вересня. У Німеччині, Іспанії, США все залежало від населеного пункту та конкретного закладу освіти, де передбачені свої навчальні плани, які мають індивідуальний характер як у кожній школі, так і в цілій провінції або навчальному окрузі.
Натепер немає єдиного міжнародного підходу щодо організації освітнього процесу. У кожній державі, у кожному регіоні, у кожному місті органи влади намагаються знайти найбільш оптимальний регламент роботи системи загальнонаціональної освіти в умовах карантинного обмеження.

31 вересня учні та студенти України повернулися до класів і аудиторій після півроку закритих шкіл, коледжів та інститутів. 2020-2021 навчальний рік в Украіні буде проходити в умовах адаптивного карантину. Це означає, що в закладах освіти 
навчання здійснюватиметься згідно з вимогами Міністерства охорони здоров'я України (далі - МО3) та рекомендаціями Міністерства освіти і науки України (далі - МОН), а також залежно від особливостей епідеміологічної ситуації в кожному конкретному регіоні, а саме: для «зеленої», «жовтої» та «помаранчевої» зон рівня епідемічної небезпеки передбачено звичний режим, для «червоної» - заборона навчання.

Це викликає занепокоєння щодо не тільки охорони здоров'я дитини, а й захисту iï суб'єктивного права на отримання безпечних умов в освітньому процесі під час карантинного обмеження.

Ці чинники спонукають до оновлення регулюючих заходів, розроблення та вжиття нових форм організації освітнього процесу, ухвалення коректних рішень щодо обмежувального впливу під час карантину та захисту безпечного права дитини в освітньому процесі з боку органів державної влади, а також посилення особистої відповідальності батьків і осіб, які їх замінюють, щодо піклування про здоров’я своїх дітей та освоєння ними навчальної програми.

Більшість публікацій із проблем, пов'язаних із пандемією, стосуються суто спеціалізованих медичних досліджень. Питанню охорони здоров'я дітей приділяли увагу Н. Бібік, М. Гончаренко, Л. Ольховик, В. Оржіховська, О. Синєгубов. Питання здобуття освіти досліджували К. Александрова, В. Масюк, Т. Ковальова, Г. Попова. Наукові напрацювання цих та інших учених становлять значне підгрунтя для даної роботи. Проте реалізація права дитини на освіту в умовах карантинних обмежень ще не була предметом наукової праці.

Мета статті - розкрити співвідношення теоретичних аспектів та практичних проблем реалізації права дитини на освіту під час дії карантинних обмежень, визначити й охарактеризувати форми навчання, які забезпечують право дитини на освіту, окреслити їхні переваги та недоліки.

Виклад основного матеріалу. У процесі навчання дитина постійно повинна адаптуватися до різного роду чинників з погляду екології, побуту, збільшення програмних навантажень та інших, які несприятливо впливають на ï здоров'я. Крім цього, нині перед дітьми постав іще один виклик - пандемія коронавірусної хвороби COVID-19. Ці чинники значно ускладнюють процес навчання, засвоєння навчального матеріалу. Для реалізації права дитини на освіту розвинута демократична держава передусім має забезпечити дитині право на охорону здоров'я. Життя та здоров'я - це найвищі пріоритети в системі людських цінностей. Особисте право на здоров'я, починаючи 3 дитинства, людина здійснює протягом усього свого життя.

Права на охорону здоров'я та на освіту проголошені нормами міжнародно-правових документів: Загальної декларації прав людини, Міжнародного пакту про економічні, соціальні та культурні права, Конвенції ООН про права дитини тощо. Конституцією України закріплено, що людина, іiї життя і здоров'я, честь і гідність, недоторканність і безпека визнаються в Україні найвищою соціальною цінністю. Права і свободи людини та їх гарантії визначають зміст і спрямованість діяльності держави. Держава відповідає перед людиною за свою діяльність. Утвердження і забезпечення прав і свобод людини є головним обов'язком держави, а також права на освіту, обов'язок держави забезпечити іï доступність і безоплатність [1].

Гарантом упровадження конституційних норм у вирішенні питань 3 охорони здоров'я дітей, їхнього права на безпечні умови освіти є норми, закріплені законами України. У Законі «Про охорону дитинства» (ст. 6) дитині гарантовано право на охорону здоров'я, медичну допомогу, отримання безпечних умов для життя і здорового розвитку. У Законі «Про повну загальну середню освіту» (ч. 1 ст. 21) визначено, що заклад освіти створює безпечне освітнє середовище 3 метою забезпечення належних і безпечних умов навчання, виховання, розвитку учнів, а також формує в них гігієнічні навички та засади здорового способу життя [6].

Також органи державної влади мають здійснювати чітку й ефективну діяльність, спрямовану на створення сприятливих умов для навчання дітей під час карантину в умовах пандемії, а також забезпечувати державний контроль за виконанням прав дітей згідно із чинними протиепідемічними заходами, які спрямовані на запобігання епідемічній ситуації через поширення коронавірусної хвороби (COVID-19).

Так, згідно із Законом України «Про захист населення від інфекційних хвороб» (ч. 5 ст. 15), працівники дитячих закладів зобов'язані вести постійне спостереження за станом здоров'я дітей, а в разі виявлення хворого на інфекційну хворобу - ужити заходів для його ізоляції від здорових дітей та негайно повідомити про цей випадок відповідний заклад охорони здоров’я [4].

Крім цього, посадові особи державної влади мають нести персональну відповідальність, визначену для засновників (власників) 
та керівників закладів освіти за організацію та виконання протиепідемічних заходів, п. 1 постанови Головного державного санітарного лікаря України Міністерства охорони здоров'я України від 22 серпня 2020 р. № 50 «Про затвердження протиепідемічних заходів у закладах освіти на період карантину у зв'язку поширенням коронавірусної хвороби (COVID-19)».

3 метою запобігання поширенню коронавірусної інфекції Урядом України ухвалено низку нормативно-правових актів щодо запровадження посилених протиепідемічних заходів на території країни. Для керівників закладів загальної середньої освіти МОН підготувало лист «Щодо організації роботи закладів загальної середньої освіти у 2020/2021 навчальному році» від 5 серпня 2020 р. № 1-9/420, рекомендований алгоритм дій керівникам закладів загальної середньої освіти в разі виявлення у здобувача освіти ознак гострого респіраторного захворювання.

Щодо надання рекомендацій та залучення батьків до безпечного навчання дітей у новому учбовому році, МОН спільно з Дитячим фондом ООН (ЮНІСЕФ) запустило інформаційну кампанію «Школо, ми готові».

У результаті проведеного аналізу чинного законодавства України можна зазначити, що інститут прав дитини з охорони її здоров'я та реалізації права на освіту декларативно має пріоритетне значення для державної політики, відповідає міжнародним стандартам у дотриманні найкращих інтересів дитини, сприяє об'єднанню зусиль відповідних інституцій і окреслює механізм забезпечення права дитини на освіту органами державної влади. Під час розгляду права дитини на освіту необхідно зазначити, що право - це благо, цінність, якою володіє дитина.

У нашій роботі ми розглядаємо реалізацію права дитини на освіту в умовах карантину як суб'єктивне цивільне право фізичних осіб, яке за своїм змістом тісно та нерозривно пов'язане з особою - носієм, не має економічної природи походження й економічного змісту, а також спрямоване на задоволення фізичних (біологічних), духовних, моральних, культурних, соціальних чи інших нематеріальних потреб (інтересу), об'єктом якого є особисте немайнове благо, а у визначених законом випадках й інше нематеріальне благо [8].

Особисті немайнові права розглядаються в сучасній доктрині і законодавстві України як абсолютні й невідчужувані, і які є виявом свободи і недоторканості особи. 3 урахуванням традицій українського законотворення, положень міжнародних конвенцій, тенденцій суспільного розвитку, досвіду демократичних країн, які визначені Конституцією України, законодавець не допускає жодних обмежень щодо можливостей цивільно-правової охорони особистих немайнових відносин [2].

Адже особисті немайнові права дитини мають свою специфіку, яка залежить від вікових особливостей. Дитина від народження наділена комплексом прав, але через свою духовну, моральну та фізичну незрілість вона обмежена в їх здійсненні. Згідно з нормами чинного законодавства, увесь комплекс повноважень зі здійснення права дитини до досягнення нею 14 років покладається на iї батьків або осіб, які їх замінюють, лише після досягнення зазначеного віку дитина має можливість особисто розпоряджатися своїм особистим правом щодо свого здоров'я й освіти. Водночас одне з основних положень Конвенції ООН про права дитини проголошує участь дітей щодо їхньої власної долі.

Згідно з нормами чинного законодавства, кожний учасник освітнього процесу може реалізувати своє право на освіту шляхом її здобуття в різних формах, на різних рівнях і різних видів.

Розглянемо, які саме форми навчання забезпечені державою 3 метою реалізації права дитини на освіту відповідно до Закону України «Про освіту» (ч. 1 ст. 9).

Основна форма здобуття освіти дітьми інституційна, до якої належать очна (денна) та дистаниійна. Така форма навчання базується на безпосередній участі дитини в освітньому процесі. Так, з 1 вересня 2020 р. більшість закладів освіти «зеленої» та «помаранчевої» зон розпочали освітній процес за очною (денна) формою навчання, коли діти відвідують заклади освіти 3 дотриманням протиепідемічних правил. Органи державної влади та місцевого самоврядування вживають протиепідемічних заходів, які передбачають механізм дій посадових осіб навчальних закладів щодо реалізації прав дітей на здобуття безпечної освіти під час карантину безпосередньо в закладах освіти, а саме: адміністрацією шкіл дотримуються вимоги щодо організації освітнього процесу шляхом використання кабінетної системи навчання, коли вчитель йде до дітей; забезпечується організація харчування та питного режиму; уживаються заходи з дезінфекції; учителями використовуються засоби індивідуального захисту тощо.

Проте, незважаючи на вищезазначене, ситуація в навчальних закладах України $€$ досить складною. У класах навчаються понад 30 дітей, отже, у таких умовах неможливо забезпечити відповідну дистанцію 
(1,5 м) між учнями. Не всі заклади освіти запровадили двозмінне навчання 3 метою проведення уроків із залученням не більше 15 осіб. Носіння захисних масок дітьми під час пересування в закладах освіти дуже важко проконтролювати.

Щодо цієї проблеми варто підтримати думку В. Махнюка, який виділяе такі причини погіршення здоров'я дітей у школі: недосконалість системи медичного обслуговування дітей в умовах школи; невідповідність матеріально-технічної бази шкіл санітарно-гігієнічним вимогам щодо водопостачання, опалення, освітлення, вентиляції; перевищення норм наповнюваності класів; збільшення навчального навантаження i, як наслідок, зменшення часу перебування школярів просто неба та скорочення тривалості їхнього сну [3].

Отже, такий стан речей у закладах освіти під час денної форми навчання в умовах адаптивного карантину можна вважати досить небезпечним. Тому батьки можуть обирати інші форми навчання - дистанційну або індивідуальну.

Відповідно до Закону України «Про освіту» (п. 3 ч. 2 ст. 55), батьки мають право обирати заклад освіти, освітню програму, вид і форму здобуття дітьми відповідної освіти [7].

Дитина має право на захист свого суб'єктивного права для досягнення здорового середовища, соціального благополуччя, душевного та фізичного комфорту, а також має можливість на юридичні дії через своїх батьків або осіб, які їх замінюють.

Зупинимось більш детально на аспектах дистаниійного навчання, яке здійснюються шляхом індивідуальної роботи учасника освітнього процесу з метою здобуття знань, формування навичок, умінь на відстані від інших учасників за допомогою різних засобів та методів (самостійна робота; навчальні заняття тощо), а також комунікативних технологій. Варто зазначити, що розвиток такої форми, як дистанційне навчання, в Україні відбувся дещо пізніше, ніж в інших країнах світу.

Нещодавно набрало чинності Положення про дистанційну форму здобуття повної загальної середньої освіти, затверджене наказом МОН від 8 вересня 2020 р. № 1115 «Деякі питання організації дистанційного навчання», зареєстроване в Міністерстві юстиції 28 вересня 2020 р. за № 941/35224 (далі - Положення), норми якого визначають дистанційне навчання як організацію освітнього процесу (за дистанційною формою здобуття освіти або шляхом використання технологій дистанційного навчання в різних формах здобуття освіти) в умовах віддаленості один від одного його учасників та їхньої зазвичай опосередкованої взаємодії в освітньому середовищі, яке функціонує на базі сучасних освітніх, інформаційно-комунікаційних (цифрових) технологій [5].

Отже, варто зазначити, що дистанційна освіта має низку переваг. Передусім вона спрямована на реалізацію суб'єктивного права учасника навчального процесу на отримання загальнонаціонального освітнього ресурсу, яке має вираження в індивідуальному підході з набуття знань, розвитку вмінь щодо самостійного пошуку інформації та ï оброблення. По-друге, дистанційна освіта передбачає як створення комфортних та безпечних умов навчання, так і економію часу, щоб, наприклад, добратися до закладу освіти. По-третє, в умовах цифрової трансформації, або діджиталізації сучасного суспільства все більше набувають попиту нові нестандартні форми навчання.

Нині окремі заклади загальної середньої освіти України за рішенням педагогічної ради вже працюють за формою дистанційної освіти. Згідно з вимогами ч. 4 п. 3 розд. 3 Положення, під час дії карантинних обмежень (застосування протиепідемічних заходів) освітній процес у закладі освіти за рішенням педагогічної ради може організовуватися у спосіб, за якого окремі теми з навчального предмета (інтегрований курс) частиною учнів класу вивчаються очно, іншою частиною учнів класу - дистанційно (в асинхронному режимі, з можливості надання учням підтримки шляхом проведення консультацій у синхронному режимі). Для учнів визначається черговість очного та дистанційного навчання з метою забезпечення рівних умов для здобуття освіти [5].

Методичне регулювання даного пункту Положення зумовлює правильний підхід до організації дистанційного навчання, проте на практиці наявні проблеми щодо створення умов та дотримання визначених вимог закладами освіти в даному напрямі. Так, деякі батьки виявляють стурбованість щодо організації процесу онлайн-навчання для своїх дітей, яке відбувається 3 використанням електронної освітньої платформи в синхронному режимі, коли учні водночас перебувають в цифровому середовищі за допомогою засобів відеоконференції по 5-6 годин на день. По-перше, навчання з використанням синхронного режиму понад 30\% порушує вимоги ч. 2 п. 7 розд. 1 Положення - педагогічні працівники самостійно визначають режим (синхронний або асинхронний) проведення окремих навчальних занять. Водно- 
час не менше $30 \%$ навчального часу, передбаченого освітньою програмою закладу освіти, організовується в синхронному режимі (решта навчального часу організовується в асинхронному режимі) [5]. По-друге, синхронний режим понад 3 години на день негативно відображається на стані здоров'я дитини. Під час роботи з комп'ютером діти мають вирішувати завдання, які вимагають значної розумової і зорової напруги. Ще два немаловажні чинник - це нервово-емоційне напруження та статистичне навантаження яке і без того знижує рухову активність сучасної дитини. За статистикою, робота за комп'ютером навіть протягом 1-2 годин викликає в 73\% дітей загальне і зорове стомлення, тоді як від звичайних навчальних занять 3'являється втома тільки в 54\% дітей.

Законодавство України не передбачає визначених чітких норм перебування дітей перед монітором комп'ютера, у зв'язку з тим, що Державні санітарні правила та норми «Влаштування i обладнання кабінетів комп'ютерної техніки в навчальних закладах та режим праці учнів на персональних комп'ютерах» від 30 грудня 1998 р. застаріли та втратили чинність відповідно до наказу МО3 від 26 червня 2017 р. № 709, а нові правила не розроблені та не затверджені. Хоча положення ч. 1 п. 9 розд. I Положення та листа МОН України «Щодо організації дистанційного навчання» від 2 листопада 2020 р. № 1/9-609 містять рекомендації 3 дотримання педагогічними працівниками санітарних правил і норм, з використанням загального визначення (щодо формування розкладу навчальних занять, рухової активності, вправ для очей, безперервної тривалості навчальної діяльності 3 технічними засобами навчання, тривалості виконання завдань для самопідготовки у позанавчальний час) [5], без посилання на конкретний документ.

Отже, необхідно зазначити, що в умовах сьогодення наявні окремі недоліки щодо дистанційної форми навчання в Україні. Передусім зазначена форма обмежує дитину в живому спілкуванні з однолітками та викладачами; також діти не володіють навичками самостійного освоєння програми та не мають досить сильної мотивації крім того, наявні проблеми щодо організації обсягу навчального навантаження в асинхронному та синхронному режимах, діти під час синхронного режиму понад 3 години на день відчувають нервово-емоційне напруження та статистичне перенавантаження відсутні сучасні вимоги та норми санітарних правил щодо безперервної тривалості навчальної діяльності з технічними засобами навчання та виконання завдань для самопідготовки в позанавчальний час. До того ж не всі заклади освіти в Україні можуть використовувати новітні цифрові технології з метою дистанційного навчання. Це прерогатива міських та приватних шкіл, які мають відповідне системотехнічне забезпечення та достатню кваліфікацію викладачів, але це $є$ значною проблемою для віддалених сільських шкіл та дітей, які взагалі не мають сучасних девайсів. Також наявна проблема фінансування із забезпечення закладів освіти дистанційними технологіями, додаткової оплати праці педагогічних працівників, які задіяні у проведенні дистанційного навчання.

Необхідно зауважити, що відповідно до чинного законодавства України забезпечення й організацію дистанційного навчання покладено на засновника навчального закладу. Водночас у багатьох країнах світу така форма навчання визнана пріоритетною та фінансується державним коштом.

Крім очної форми навчання (денна та дистанційна), діти також можуть навчатися за індивідуальною формою, яка передбачає екстернатне, сімейне або домашнє навчання. Законом України «Про освіту» (ч. 1 ст. 53) передбачено, що здобувачі освіти мають право на індивідуальну освітню траєкторію, що реалізується, зокрема, через вільний вибір видів, форм і темпу здобуття освіти, закладів освіти і запропонованих ними освітніх програм, навчальних дисциплін та рівня їхньої складності, методів і засобів навчання [7].

А. Хуторський розглядає індивідуальну освітню траєкторію як персональний шлях реалізації особистісного потенціалу кожного учня в освіті та стверджує, що особистісний потенціал - це сукупність його діяльних, пізнавальних, творчих, комунікативних та інших здібностей [12, с. 101].

Індивідуальне навчання реалізує право вибору здобувачем форми освіти, методів навчання, а також самостійного шляху реалізації сукупності своїх можливостей. До того ж вищезазначені форми здобуття освіти передбачають забезпечення батьками освітнього процесу своїх дітей із метою здобуття ними повної загальної середньої освіти, під час здійснення якого відповідальність за освітній процес покладається на батьків, а оцінювання дітей відбувається на рівні стандартів відповідно до чинного законодавства.

Окреслені форми навчання є способами здобуття дитиною освіти в безпечних умовах під час дії карантинних обмежень на підставі поданої батьками до адміністрації закладу 
загальної середньої освіти заяви. Дитина має можливість задовольнити свої законні інтереси щодо реалізації свого суб'єктивного права на сприятливі умови зі здобуття освіти за допомогою батьків. Органи освіти зобов’язані сприяти реалізації права дитини на індивідуальну освітню траєкторію, надавати освітні послуги за потребою дитини, а також забезпечувати розвиток різних форм здобуття освіти, визначених законодавством.

3 огляду на наведене доходимо висновку, що вибір батьками форм та видів навчання для своєї дитини залежить від їхнього виваженого рішення, оцінки переваг та недоліків вказаних форм навчання, урахування побажання та думки своєї дитини для того, щоб не нашкодити їй, за збереження фізичного здоров'я, 3 порушенням психологічного стану та загального самопочуття через відсутність живого спілкування 3 однолітками, деяке обмеження щодо повноцінної реалізації й адаптації дитини в соціумі. У такому разі доцільно знайти розумний підхід, щоби, з одного боку, захистити дитину, а з іншого - не позбавляти її права вирішувати власну долю.

\section{Висновки}

Отже, реалізація права дитини на освіту належить до першочергових державних пріоритетів. Дане право забезпечується органами державної влади, ефективність та дієвість яких залежить не тільки від закріплених норм права у визначеному питанні, а й від послідовних, цілеспрямованих дій уповноважених суб’єктів та персональної відповідальності їхніх посадових осіб, завдяки яким держава зможе забезпечити захист здоров'я дитини й оптимальний процес ії навчання, а також батьками й особами, які їх замінюють, шляхом виконання зобов'язань щодо піклування про фізичне і психічне здоров'я своєї дитини, підтримки їі у виконанні освітньої програми, ужиття заходів щодо розвитку її здібностей, мотивування у формуванні навичок здорового способу життя.

Крім того, як убачається 3 наведеного матеріалу, доцільно було б удосконалити нормативну-правову базу в контексті дистанційного навчання. Сучасний темп життя в час цифрової революції та непередбачувані події, спричинені пандемією, диктують нові вимоги до розвитку освітнього процесу. На наш погляд, нині доречно ухвалити Державну програму щодо розвитку дистанційної форми здобуття освіти, яка повинна визна- чати не тільки методичні засади та механізми організації процесу такої форми навчання, a й передбачати цільове фінансування закладів освіти на рівні державного та місцевих бюджетів із метою покращення системотехнічної бази навчальних закладів. До того ж наявна потреба в ухваленні сучасних вимог або Санітарних правил щодо встановлення режиму праці учнів на персональних комп'ютерах. Отже, така форма, як дистанційне навчання є важливим аспектом у розвитку концепції системи освіти, що підлягає подальшому вивченню та практичному застосуванню.

\section{Список використаних джерел:}

1. Конституція України : Закон України. Відомості Верховної Ради Украӥни. 1996. № 30. Ст. 141. URL: https://zakon.rada.gov.ua/ laws/show/995_021\#Text.

2. Кохановська О. Поняття та види особистих немайнових прав у цивільному праві України. Юридичні науки. 2010. № 84. URL: http:// www.irbis-nbuv.gov.ua/cgi-bin/irbis_nbuv/cgiirbis.

3. Махнюк В. Гігієнічна оцінка умов і організації навчання дітей у міських та сільських загальноосвітніх навчальних закладах в період реформування освіти України : автореф. дис. ... канд. мед. наук: 14.02.01. Київ, 2007. 20 с.

4. Про захист населення від інфекційних хвороб : Закон України. Відомості Верховної Ради України. 2000. № 29. Ст. 228. URL: https:// zakon.rada.gov.ua/laws/main/1645-14.

5. Положення про дистанційну форму здобуття повної загальної середньої освіти, затверджене наказом МОН від 8 вересня 2020 р. № 1115 «Деякі питання організації дистанційного навчання», зареєстровано в Міністерстві юстиції 28 вересня 2020 р. за № 941/35224. URL: https:// zakon.rada.gov.ua/laws/show/z0941-20\#Text.

6. Про повну загальну середню освіту : Закон України. Відомості Верховної Ради України. 2020. № 31. Ст. 226. URL: https://zakon.rada.gov.ua/ laws/show/463-20\#Text.

7. Про освіту : Закон України. Відомості Верховної Ради України. 2017. № № 38-39. Ст. 380. URL: https://zakon.rada.gov.ua/laws/show/ 2145-19\#Text.

8. Стефанчук Р. Особисті немайнові права фізичних осіб у цивільному праві (поняття, зміст, система, особливості здійснення та захисту): монографія ; НАН України, Інститут держави і права ім. В.М. Корецького. Київ : КНТ, 2008. 625 с. C. 131.

9. Хуторской А. Дидактическая эвристика Теория и технология креативного обучения Москва : изд.-во МГУ, 2003, 416 с. 
Svitlana Seminoh. Realization of the children's rights for education in terms of the quarantine

The article is dedicated to the analysis of the theoretical aspects and practical problems concerning the realization of the children's rights for education in terms of the quarantine during COVID-19 pandemic. It is stated, that through the realization's imperative of the children's rights for education, the simultaneous provision of the healthcare right should be implemented. The observation of the international legal treaties and the key moments of the internal legislation in the aforementioned context were conducted. It is concluded, that the children's healthcare and the realization of the children's rights for education - are the essential tasks of the state politics, which, firstly, denotes the mechanism of the provision of such rights through the international acts and, secondly, determines the right's system, aimed at the protection of the children's rights on a national level, thirdly, it establishes the legal actions that are realized by a certain institutions and legal entities. The ways of realization of the subjective children's rights during the quarantine were researched. The ways of obtaining the education were pinpointed and characterized, with the help of which the child has an opportunity to be provided with safe environment during the educational process - day studying and individual, which provides extern, family and homeschooling. In the article the attention concentrated at the distant learning. It is emphasized, that such kind of obtaining the education is urgent nowadays and should be guaranteed as convenient and safe for children. There are some disadvantages and issued that were derived, which exist in the governmental regulation of the financial issue and providing schools with the technological simultaneous devices, and the limitation in terms of the children's communication with peers, emotional tension and the tiredness during online lessons. The conclusion was drawn, that the children's right for education is sustained with legal acts, according to which the authorities provide its realization through organization of exact actions from the corresponding institutions and executives and the child as a specific legal entity realizes his/her rights through natural parents or foster parents, who take part in the safe educational process. The improvements of the legal base was suggested in the context of the distant learning through the accepting of the State program concerning obtaining education through distant learning.

Key words: children, child's rights, protection of child's rights, realization of child's right to education, day studying, distant studying, individual form of education, quarantine restrictions, pandemic, COVID-19. 